branches of trees, which cannot possibly be the natural method. For several centuries the common swallow has disported itself in our crowded cities, and with its friendly masonry attached itself to our houses. The chimney swallow, still more familiar and audacious, often builds in the smoky shafts of our domiciles, or even in the noisiest factories, undisturbed by the din or the fires or the movement around them. Such habits must form a strong contrast with those of their predecessors in times long gone by. When we ourselves wandered untutored savages in the prehistoric times, or when still later we constructed lacustrine towns, or megalithic monuments, the habits of the birds can scarcely have been identical with those of to-day, for such human edifices afforded little security or shade. They must then have built amongst rocks. Nearly the same remarks apply to the storks, which have not remained stationary, but have preferred to their less commodious dwellings those offered to them by man. These changes in the industry or the manners of birds are perhaps even more rapid than we might at first sight suppose ; and $M$. Pouchet's observations have demonstrated to him that notable improvements have been adopted by swallows in their modification during the first half of the present century. Having directed a number to be collected for the purpose of having drawings made from them, $M$. Pouchet was astonished to find that they did not resemble those he had collected some forty years ago, and which were still preserved in the museum of Rouen. The present generation of swallows have notably improved on the architecture of their forefathers, amongst those still building in the arches and against the pillars of the churches. Some, however, still adhere to the old methods, or such nests may possibly have been old ones which have undergone reconstruction. In the streets, on the other hand, all the nests appeared to be constructed on the new method. And now for the differences observed. The old nests show, and all ancient writers as Vieillot, Montbrillard, Rennie, Deglaud, \&c., describe the nest of the houseswallow as globular, or as forming a segment of a spheroid with a very small rounded opening, scarcely permitting the ingress and egress of the couple that inhabit it. The new nests, on the contrary, have the form of the quarter of a hollow semi-oval (le quart d'un demi-ovoide creux), with very elongated poles, and the three sectional surfaces of which adhere to the walls of edifices throughout their whole extent, with the exception of the upper one, where the orifice of the nest is situated; and this is no longer a round hole, but a very long transverse fissure formed below by an excavation of the border of the section, and above by the wall of the building to which the nest is attached. This opening has a length of nine or ten centimetres and a height of two centims. $M$. Pouchet considers this new form affords more room for the inmates and especially for the young which are not so crowded, whilst they can put out their heads for a mouthful of fresh air, and their presence does not interfere with the entrance and exit of the parents. Lastly, the new form protects the inhabitants of the nest better than the old one, from rain, cold, and foreign enemies.

\section{THE ROTUNDITY OF THE EARTH}

$A$ RECENT number of the Field contains an account of a very amusing investigation which has been recently conducted on the Bedford Level to settle the question whether the earth is a globe or not! It appears that a Mr. Hampden threw out a challenge by which he offered to pay 500l. to anyone who would prove the rotundity, which challenge has been taken up by $\mathrm{Mr}$. A. R. Wallace, who has lodged a similar sum with the Editor of the Field. To test this point, six miles of the Bedford Level were used, three signals, each 13 feet 4 inches above the water level, being put up three miles apart. Mr. Wallace asserted that if he were correct the central signal would appear elevated about 5 feet above the line joining the other two; Mr. Hampden holding, of course, that they would all be in the same straight line. It is needless to say what the result was, but we now come to a part of the story which is not so amusing, and here we quote from the Field:-

Both Mr. Hampden and Mr. Carpenter assented to the details of this experiment in our presence as conclusive, although we regret to say that Mr. Carpenter alleged his opinion was founded upon theory alone, and that it had never, as far as he knew, been tried. Now, the fact really is, that in a little treatise published by "Parallax," and which we have now in our possession, with Mr. Carpenter's name on the title-page, in his own handwriting, an experiment similar in its nature is described as having been made on the very same piece of water as that on which we were then occupied, with a result exactly the reverse of that which recently occurred. Mr. Carpenter was, in fact, engaged to decide a disputed question of which he and his principal professed to be practically ignorant, although it was in print on the authority of the head of their sect that it had already been tried in the same locality; and this mast have been then known to Mr. Carpenter, and has since been admitted by hin in our presence. The good faith and perfect fairness of $\mathrm{Mr}$. Carpenter were not, therefore, quite of the nature we then believed them to be, and we have no hesitation in affirming that he was a most improper person to be selected to act as referee in such a matter. The deception was, to say the least of it, "unscientific;" yet Mr. Carpenter and his master, "Parallax," both profess to be ardent in the cause of science; and that it has recoiled upon their heads can cause no regret to anyone who values the truth.

Although the diagrams of what was seen by the telescopes used at both ends, and acknowledged to be correct by Mr. Carfenter and Mr. Hampden, show the central signal more than 5 feet above the line of the two extremes, these gentlemen coolly claim the victory, and threaten to bring an action against the Editor of the Field (who was appointed umpire by Mr. Fiampden himself) for fraudulently deciding against them.

\section{LETTERS TO THE EDITOR}

[The Editor does not hold himself responsible for opinions expressed by his Correspondents. No notice is taken of anonymous communications.]

On Prof. Tyndall's Exposition of Helmholtz's Theory of Musical Consonance

IN NATURE for March 3 you published a letter of mine, in which I stated that the exposition of Helmholtz's theory of musical consonance given in Prof. Tyndall's lectures on Sound was both "radically different from the original, and erroneous." I supported my assertion by a series of arguments which, both to myself and to other competently informed persons, appeared conclusive.

Prof. Tyndall has taken no notice. public or private, of my letter, although he has since its publication written in your columns on another subject.

Your readers, as well as myself, are surely justified in calling on Prof. 'Tyndall either to rebut my argument or admit my conclusion.

Trinity College, Cambridge, March 29 SedLeY TAyLOR

[Prof. Tyndall's Lectures on Sound have been translated into German, and the following is a verbatim copy of the "Vorwort des Herausgeber":-

"Die Vorlesungen welche Herr Tyndall als Nachfolger der. grossen Naturforscher Davy und Faraday in dem Wintermonaten vor den geb:ldesten Kreisen Londons in der Royal Institution iiber die verschiedenen Theile der Physik zuhalten pflegt, haben in England allzeitige Anerkennung gefunden. Herr Tyndall hesitzt in ungewöhnlichem Grade die Gabe, durch die glückliche Vereinigung einer eben so klaren wie eleganten Darstellung, mit vortrefflich ersonnenen und schlagenden Versuchen selbst die schwierigeren Lehren der Physik dem gebildeten Publikum zuyänglich zu machen. Eine Heraussabe seiner Vorlesungen in deutscher Bearbeitung dürfte desshalb auch bei uns nicht wenig zur Verbreitung physikalischer Kenntnisse in weiteren Kreisen beitragen. Die Unterzeichneten haben 